\title{
ANALISIS PENGARUH MODAL KERJA TERHADAP PROFITABILITAS PADA PERUSAHAAN MANUFAKTUR YANG TERDAFTAR DIBURSA EFEK INDONESIA (BEI)
}

\author{
Dwi Agustyawati \\ Program Studi Manajemen, Fakultas Ekonomi \\ Universitas Muhammadiyah Buton, Baubau, Indonesia \\ e-mail: partyazh@gmail.com
}

\begin{abstract}
ABSTRAK
Modal kerja menjadi hal yang penting dibahas dalam usaha meningkatkan profitabilitas dikarenakan modal kerja merupakan pembelanjaan jangka pendek perusahaan yang diharapkan akan dapat kembali lagi masuk dalam perusahaan dalam waktu jangka pendek. Hal ini seiring dengan tujuan utama perusahaan yaitu meningkatkan profitabilitas dikarenakan modal kerja berperan dalam menopang operasi serta kegiatan perusahaan. Adanya modal kerja yang cukup memungkinkan bagi perusahaan untuk beroperasi dengan seekonomis mungkin sehingga perusahaan tidak akan mengalami kesulitan keuangan.

Penelitian ini bertujuan untuk mengetahui dan menganalisis pengaruh modal kerja terhadap profitabilitas pada perusahaan manufaktur yang terdaftar diBursa Efek Indonesia. Objek penelitian ini adalah 30 perusahaan manufaktur yang terdaftar diBursa Efek Indonesia pada sektor industri barang konsumsi.Data laporan keuangan yang digunakan adalah laporan keuangan perusahaan selama 3 tahun terakhir, dari tahun 2015 - 2017. Jenis data dalam penelitian ini adalah data kuantitatif. Metode yang digunakan dalam penelitian ini adalah metode analisis regresi linear sederhana. Metode pengumpulan data yang digunakan adalah metode dokumentasi. Untuk mendapatkan tingkat akurasi dan dapat mengetahui apakah terdapat pengaruh yang signifikan antara variabel independent (modal kerja) terhadap variabel dependent (Profitabilitas) dengan menggunakan persamaan perhitungan modal kerja dan persaam perhitungan profitabilitas. Dari penelitian ini dapat diketahui bahwa modal kerja memberikan hasil yang signifikan terhadap return on total asset( ROA). Hasil penelitian menunjukan bahwa modal kerja berpengaruh terhadap profitabilitas pada perusahaan manufaktur yang terdapat dibursa efek indonesia pada sektor industri barang konsumsi. Hal ini dapat dilihat dari nilai $\mathrm{t}_{\text {hitung }}$ lebih besar dari nilai $\mathrm{t}_{\text {tabel }}: 0,211>2,048$.
\end{abstract}

Kata Kunci : Modal Kerja, Profitabilitas, Return On Asset (ROA)

\begin{abstract}
Working capital becomes an important issue discussed for profitability, as working capital is shortterm expenditure of the company, which is expected to return to the company in the short-term. This is consistent with the company's primary goal of increasing profitability, as working capital plays a role in supporting the company's operations and activities. The existence of working capital is quite possible for the company to work as economically as possible so that there are no financial difficulties for the company.

The purpose of this study is to determine and analyze the impact of working capital on the profitability of manufacturing companies listed on the Indonesian Stock Exchange. The subject of this investigation are 30 manufacturing companies registered in the consumer goods industry on the Indonesian Stock Exchange. The financial statements used are the company's financial statements for
\end{abstract}


the past 3 years from 2015 to 2017. The data types used in this study are quantitative data. The method used in this study is a simple linear regression analysis. The data collection method used is the documentation method. Determine the level of accuracy and determine whether there is a significant impact between the independent variables (working capital) and the dependent variable (profitability). Use the equation to calculate working capital and calculate profitability. The study shows that working capital provides significant returns on ROA. The results showed that working capital affects the profitability of manufacturing companies that have Indonesian securities in the consumer goods sector. This can be seen from the value of t count, which is greater than the value of $t$ table: $0.211>2.048$.

Keywords: Working Capital, Profitability, Return on Assets (ROA).

\section{PENDAHULUAN}

Meningkatnya kesejahteraan masyarakat, berpengaruh terhadap meningkatnya kebutuhan akan barang dan jasa. Hal ini menjadi peluang dan tantangan buat Perusahaan-Perusahaan domestik untuk mengambil peran dalam mencukupi kebutuhan masyarakat tersebut.Dengan perkembangan teknologi dan dunia usaha yang sangat cepat saat ini, persaingan antar perusahaan juga akan semakin ketat.

Untuk mencapai kelangsungan hidup perusahaan tidak terlepas dari peranan sumber daya manusia yang melakukan peningkatan-peningkatan mutu dari hasil pekerjaan yang telah dilakukannya. Setiap perusahaan akan melakukan berbagai aktivitas operasional untuk menjamin kelanjutan perusahaan dengan menghasilkan laba yang optimal. Perusahaan selalu memerlukan dana untuk membiayai aktivitas operasional sehari-hari dan untuk membiayai investasi jangka panjang perusahaan. Dana yang digunakan untuk membiayai kegiatan operasional perusahaan tersebut adalah modal kerja.

Tujuan utama perusahaan pada umumnya ialah memperoleh laba atau keuntungan yang semaksimal mungkin. Bagi suatu perusahaan untuk memperoleh laba yang semaksimal mungkin, dapat dilakukan dengan memperbesar jumlah produksi yang dapat dijual. Salah satu faktor yang terpenting ialah modal kerja yang digunakan perusahaan untuk membiayai operasi perusahaan demi menjamin kelangsungan hidup perusahaan. Modal kerja adalah dana yang ditanamkan ke dalam aktiva lancar untuk membiayai operasi perusahaan sehari-hari [1].

Modal kerja menjadi hal yang penting dibahas dalam usaha meningkatkan profitabilitas dikarenakan modal kerja merupakan pembelanjaan jangka pendek perusahaan yang diharapkan akan dapat kembali lagi masuk dalam perusahaan dalam 
waktu jangka pendek. Hal ini seiring dengan tujuan utama perusahaan yaitu meningkatkan profitabilitas dikarenakan modal kerja berperan dalam menopang operasi serta kegiatan perusahaan. Adanya modal kerja yang cukup memungkinkan bagi perusahaan untuk beroperasi dengan seekonomis mungkin sehingga perusahaan tidak akan mengalami kesulitan keuangan.

Bagi perusahaan yang sudah go public, modal kerja selain dapat diperoleh dari pinjaman dari pihak Bank, modal juga dapat diperoleh melalui instrumen keuangan di pasar modal atau di Bursa Efek Indonesia (BEI) dengan melepas sebagian saham kepemilikan atau dengan menerbitkan obligasi ke investor. Perusahaan harus selalu menjaga profitabilitasnya agar dapat stabil sehingga investor tertarik untuk berinvestasi pada perusahaan tersebut karena sebelum berinvestasi para investor biasanya memfokuskan pada analisis profitabilitas perusahaan. Dengan profitabilitas yang stabil perusahaan dapat menjaga kontinuitas perusahaan, sebaliknya apabila perusahaan tidak mampu untuk menghasilkan profitabilitas yang baik maka perusahaan tidak akan mampu menjaga kelangsungan usahanya. Perusahaan harus selalu meningkatkan efisiensi kerjanya sehingga dapat mencapai profitabilitas yang optimal.

Modal kerja adalah aktiva lancar dikurangi hutang lancar atau dana yang harus tersedia untuk membiayai kegiatan operasi perusahaan sehari-hari, misalnya untuk membayar gaji pegawai, membeli bahan baku, membayar hutang dan sebagainya. Dana yang dialokasikan tersebut diharapkan diterima kembali dari hasil penjualan produk yang dihasilkan dalam waktu yang tidak lama (satu tahun atau kurang dari satu tahun). Dengan demikian, sumber dana tersebut akan terus-menerus berputar setiap periodenya selama hidupnya perusahaan [2].

Modal kerja harus cukup jumlahnya dalam arti harus mampu membiayai pengeluaran-pengeluaran atau operasi perusahaan sehari-hari, aktivitas yang di laksanakan perusahaan akan memerlukan dana, baik untuk membiayai kegiatan seharihari maupun kegiatan operasional dan membiayai waktu jangka panjangnya investasi tersebut [3].

Manajemen modal kerja yang baik akan menghasilkan operasional perusahaan tetap akan berjalan dengan baik dan tidak akan ada masalah dalam keuangan. Manajemen modal kerja akan berpengaruh terhadap profitabilitas perusahaan [4]. Pimpinanan perusahaan dapat mengetahui berhasil atau tidaknya perusahaan yang 
dipimpinnya dari profitabilitas yang diperoleh perusahaan, sedangkan bagi investor dapat digunakan sebagai tolok ukur modal yang ditanamkan dalam perusahaan tersebut [5].

Kemampuan perusahaan untuk menghasilkan laba selama periode tertentu disebut profitabilitas."'Rasio profitabilitas merupakan rasio untuk menilai kemampuan perusahaan untuk mencari keuntungan [6]. Profitabilitas dapat digunakan sebagai tolak ukur untuk menilai keberhasilan dari suatu perusahaan dalam menjalankan usahanya dan juga dapat digunakan sebagai tolak ukur dalam menilai prospek return dari modal yang akan ditanamkan oleh investor. Sedangkan bagi perusahaan rentabilitas dapat digunakan untuk menilai kemampuan perusahaan dalam menggunakan modal kerja secara efektif untuk menghasilkan tingkat laba tertentu yang diharapkan [7].

Modal kerja yang telah dikeluarkan oleh perusahaan diharapkan untuk kembali masuk diperusahaan dalam jangka waktu yang pendek dari perolehan penjualan hasil produksi. Adanya suatu modal kerja bagi perusahaan yang menguntungkan karena disamping bagi perusahaan untuk melakukan kegiatan operasional secara efisien sehingga tidak akan mengalami kesulitan keuangan pada perusahaan tersebut, perusahaan dalam menjalankan bisnisnya dituntut untuk mencapai tujuan yang telah diterapkan. Dengan demikian, penelitian ini bertujuan untuk mengetahui bagaimana pengaruh Modal Kerja Terhadap Profitabilitas Pada Perusahaan Manufaktur Yang Terdaftar Di Bursa Efek Indonesia.

\section{METODE PENELITIAN}

Jenis data dalam penelitian ini adalah data kuantitatif, yaitu data yang dinyatakan dalam bentuk angka-angka [8].Data kuantitatif dalam penelitian ini yaitu berupa laporan keuangan dari perusahaan manufaktur. Objek penelitian adalah 30 perusahaan manufaktur yang terdapat di Bursa Efek Indonesia. Dalam penelitian ini, data yang diperoleh adalah data sekunder. Data sekunder adalah data yang dikumpulkan dari sumber yang sudah ada. Sumber data sekunder adalah dokumentasi perusahaan, publikasi pemerintah, analisis industry oleh media, situs web, dan lain sebagainya [9] data sekunder dalam penelitian ini adalah laporan tahunan perusahaan manufaktur sektor industri dan telah dipublikasikan, seperti data-data dari Bursa Efek Indonesia, Badan Pengawas Pasar Modal (BAPEPAM), Pusat Referensi Pasar Modal (PRPM), Jurnal, Internet www.idx.co.id dan website perusahaan yang bersangkutan. 
Metode pengumpulan data yang digunakan adalah metode dokumentasi yaitu menyelidiki benda-benda tertulis seperti buku-buku, dokumen, catatan harian dan sebagainya [10]. Metode analisis data yang digunakan yaitu menggunakan regresi sederhana. Model regresi linier sederhana merupakan sebuah metode statistika untuk melakukan identifikasi pengaruh satu variabel (X) bebas terhadap 1 variabel terikat (Y) [11]. Untuk mendapatkan tingkat akurasi dan dapat mengetahui apakah terdapat pengaruh yang signifikan antara variabel independent (modal kerja) terhadap variabel dependent (Profitabilitas).Metode analisis data yang digunakan adalah sebagai berikut :

a. Perhitungan modal kerja

Modal kerja $=$ total aktiva lancar - total utang lancar [12]

b. Perhitungan profitabilitas

$R O A=\frac{\text { Laba Setelah pajak }}{\text { total aktiva }} \times 100 \%[13]$

1. Metode regresi linier sederhana untuk mengukur besarnya pengaruh variabel independen terhadap variabel dependen. Dengan persamaan umum Regresi Linear Sederhana sebagai berikut : $\mathbf{Y}=\mathbf{a}+\mathbf{b X}$

Dimana: $Y=$ profitabilitas

$$
\begin{aligned}
& a=\text { konstanta } \\
& b=\text { koefisien regresi } \\
& X=\text { modal kerja }
\end{aligned}
$$

\section{Uji Hipotesis}

Uji $\mathrm{t}$ adalah pengujian terhadap masing-masing variabel independen. Uji $\mathrm{t}$ (cofficient)akan dapat menunjukkan pengaruh masing-masing variabel independent terhadap variabel dependen [14]. Hipotesisnya yang digunakan :

1) Jika t tabel > t hitung maka $\mathrm{HO}$ diterima, modal kerja tidak berpengaruh signifikan terhadap profitabilitas

2) Jika t tabel < t hitung maka HO ditolak, modal kerja berpengaruh signifikan terhadap profitabilitas

Dalam pengelolaan uji t statistik bertujuan melihat seberapa besar pengaruh masing-masing variabel independen (modal kerja) terhadap variabel dependen (profitabilitas).

3. Uji koefisien determinasi $\left(\mathrm{r}^{2}\right)$, Koefisien determinasi yaitu mengukur seberapa jauh kemampuan model dalam menerangkan variasi variabel dependen [15]. 
Dalam penelitian ini analisis untuk mengetahui seberapa besar sumbangan atau kontribusi variabel independen (modal kerja) terhadap variabel dependen (profitabilitas). Besar koefisien determinasi $\left(\mathrm{R}^{2}\right)$ didapat dari menguadratkan koefisien korelasi (r).

$\mathrm{R} 2=\frac{n\left(\sum X Y\right)-\left(\sum X\right)\left(\sum Y\right)}{\sqrt{\left[n\left(\sum X^{2}\right)-\left(\sum X\right)^{2}\right]\left[n\left(\sum Y^{2}\right)-\left(\sum Y\right)^{2}\right]}}$

Keterangan :

$\mathrm{R}^{2}=$ Koofisien Determinasi

$\sum X=$ Jumlah skor variabel $\mathrm{X}$

$\sum Y=$ Jumlah skor variabel $Y$

$\sum X Y=$ Jumlah skor Variabel $\mathrm{XY}$

$\sum X^{2}=$ Jumlah skor variabel $X$ yang dikuadratkan

$\sum Y^{2}=$ Jumlah skor variabel $Y$ yang dikuadratkan

$n \quad=$ Jumlah sampel

\section{HASIL DAN PEMBAHASAN}

\section{a. Hasil Penelitian}

\section{a) Deskripsi Variabel Penelitian}

1) Analisis Variabel Independent Modal Kerja

Tabel 1. Modal Kerja

\begin{tabular}{|c|c|c|c|c|c|}
\hline No & Nama Perusahaan & $\begin{array}{c}2015 \\
\text { (Rp juta) }\end{array}$ & $\begin{array}{c}2016 \\
\text { (Rp juta) }\end{array}$ & $\begin{array}{c}2017 \\
\text { (Rp juta) }\end{array}$ & AVG \\
\hline 1 & $\begin{array}{lrr}\text { PT. Akasha } & \text { Wira } \\
\text { International Tbk. } & \end{array}$ & 76.959 & 124.148 & 49.356 & 83 \\
\hline 2 & $\begin{array}{l}\text { PT.TigaPilar Sejahtera Food } \\
\text { Tbk. }\end{array}$ & 1.713 .178 & 3.444 .834 & 634.174 & 1 \\
\hline 3 & PT. Tri Banyan Tirta Tbk. & 204.622 .773 & -81.711 .715 & 13.458 .752 & 45 \\
\hline 4 & $\begin{array}{lll}\text { PT. Wilmar } & \text { Cahaya } \\
\text { Indonesia Tbk. } & \end{array}$ & 436.547 .773 & 599.656 .484 & 544.096 .879 & 52. \\
\hline 5 & PT.Delta Djakarta Tbk & 761.587 .338 & 910.291 .601 & 1.066 .891 .281 & 91 \\
\hline 6 & $\begin{array}{l}\text { PT. Indofood CBP Sukses } \\
\text { Makmur Tbk }\end{array}$ & 7.959 .156 & 9.101 .577 & 9.751 .743 & 8 \\
\hline 7 & $\begin{array}{l}\text { PT. Indofood } \text { Sukses } \\
\text { Makmur Tbk }\end{array}$ & 17.709 .207 & 9.766 .002 & 10.877 .636 & 12 \\
\hline 8 & PT. Multi Bintang Indonesia & -505.272 & -425.003 & -227.269 & -3 \\
\hline
\end{tabular}




\begin{tabular}{|c|c|c|c|c|c|}
\hline & Tbk & & & & \\
\hline 9 & PT. Mayora Indah Tbk & 4.302 .852 & 4.855 .731 & 6.200 .571 & 5 \\
\hline 10 & $\begin{array}{l}\text { PT. Prasidha Aneka Niaga } \\
\text { Tbk }\end{array}$ & 25.393 .750 & 19.719 .864 & 53.098 .034 & 32 \\
\hline 11 & $\begin{array}{l}\text { PT. Nippon Indosari } \\
\text { Corpindo Tbk }\end{array}$ & 417.070 & 628.912 & 1.292 .760 & 77 \\
\hline 12 & PT. Sekar Laut Tbk & 30.626 .073 & 53.384 .288 & 55.636 .319 & 46 \\
\hline 13 & PT. Siantar Top Tbk & 105.200 & 362.946 & 589.022 & 35 \\
\hline 14 & PT. Ultrajaya Milk Industry & 1.541 .937 & 2.281 .296 & 2.619 .365 & 2 \\
\hline 15 & $\begin{array}{l}\text { PT. Campina Ice Cream } \\
\text { Industri }\end{array}$ & 48.387 & 50.151 & 80.988 & 59 \\
\hline 16 & PT.Sariguna Primatirta TBK & -39.126 & -60.994 & 27.335 & -21 \\
\hline 17 & $\begin{array}{l}\text { PT.Buyung Poetra Sembada } \\
\text { TBK }\end{array}$ & 30.223 & 46.794 & 314.362 & 13 \\
\hline 18 & PT.Sekar Bumi & 3.650 & 5.029 & 32.504 & 13 \\
\hline 19 & PT.Gudang Garam TBK & 18.523 & 20.294 & 21.153 & 19 \\
\hline 20 & PT.HM Sampoerna TBK & 25.269 & 27.219 & 27697 & 26 \\
\hline 21 & $\begin{array}{l}\text { PT.Bentoel Internasional } \\
\text { Investama TBK }\end{array}$ & 4.147 & 5.082 & 4.317 & 4 \\
\hline 22 & $\begin{array}{l}\text { PT.Wismilak Inti Makmur } \\
\text { TBK }\end{array}$ & 647.109 & 703.214 & 700.382 & 68 \\
\hline 23 & PT.Indofarma TBK & 221.427 & 148.574 & 37.289 & 13 \\
\hline 24 & $\begin{array}{l}\text { PT.Kimia Farma (persero) } \\
\text { TBK }\end{array}$ & 1.008 .298 & 1.210 .528 & 1.292 .583 & 11 \\
\hline 25 & PT.Merck TBK & 351.244 & 387.993 & 384.918 & 37 \\
\hline 26 & PT.Kino Indonesia TBK & 798.875 & 655.379 & 709.839 & 72 \\
\hline 27 & PT.Martina Berto TBK & 318.243 & 317.477 & 268.136 & 30 \\
\hline 28 & PT.Mustika Ratu TBK & 278.090 & 278.860 & 277.449 & 27 \\
\hline 29 & PT.Mandom Indonesia TBK & 889.742 & 953.902 & 1.016 .672 & 95 \\
\hline 30 & PT.Hartadinata Abadi TBK & 315.152 & 486.477 & 965.566 & 58 \\
\hline
\end{tabular}

Sumber: Bursa Efek Indonesia (Data Diolah)

Dari tabel 1 untuk data modal kerjanya dinyatakan dalam satuan rupiah (Rp juta). Dan untuk menghitung rata-rata modal kerja dari tahun 2015,2016,dan 2017 menggunakan average pada MS. Excel.Untuk nilai AVG (average) pada table 1 adalah untuk menghitung nilai rata-rata modal kerja perusahaan dari tahun 2015, 2016, 2017. 


\section{2) Analisis Variabel Dependent Return on Asset}

Tabel 2. Return on Asset

\begin{tabular}{|c|c|c|c|c|c|}
\hline No & Nama Perusahaan & $2015(\%)$ & $2016(\%)$ & $2017(\%)$ & AVG \\
\hline 1. & PT. Akasha Wira International Tbk. & 5,02 & 7,29 & 4,55 & 5,62 \\
\hline 2. & PT. Tiga Pilar Sejahtera Food Tbk. & 4,12 & 7,77 & $-9,70$ & $\mathbf{0 , 7 3}$ \\
\hline 3. & PT. Tri Banyan Tirta Tbk. & $-2,06$ & $-2,27$ & $-5,66$ & $-3,33$ \\
\hline 4. & PT. Wilmar Cahaya Indonesia Tbk. & 7,17 & 17,51 & 7,71 & 10,79 \\
\hline 5. & PT. Delta Djakarta Tbk & 18,49 & 21,24 & 20,86 & 20,19 \\
\hline 6. & PT. Indofood CBP Sukses Makmur Tbk & 11,00 & 12,56 & 11,20 & $\mathbf{1 1 , 5 8}$ \\
\hline 7. & PT. Indofood Sukses Makmur Tbk & 4,03 & 6,40 & 5,85 & 5,42 \\
\hline 8. & PT. Multi Bintang Indonesia Tbk & 23,65 & 43,16 & 52,67 & 39,82 \\
\hline 9. & PT. Mayora Indah Tbk & 11,02 & 10,74 & 10,93 & 10,89 \\
\hline 10. & PT. Prasidha Aneka Niaga Tbk & $-6,86$ & $-5,60$ & 4,65 & $-2,60$ \\
\hline 11. & PT. Nippon Indosari Corpindo Tbk & 9,99 & 9,58 & 2,96 & 7,51 \\
\hline 12. & PT. Sekar Laut Tbk & 5,32 & 3,63 & 3,61 & 4,18 \\
\hline 13. & PT. Siantar Top Tbk & 9,67 & 7,45 & 9,22 & 8,78 \\
\hline 14. & PT. Ultrajaya Milk Industry & 14,77 & 16,74 & 13,72 & 15,07 \\
\hline 15. & PT.Campina Ice Cream Industry Tbk & 7,37 & 5,12 & 3,59 & 5,36 \\
\hline 16. & PT. Sariguna Primatirta Tbk & 1,39 & 8,48 & 7,60 & 5,82 \\
\hline 17. & PT. Buyung Poetra Sembada Tbk & 16,04 & 11,84 & 8,32 & 12,06 \\
\hline 18. & PT. Sekar Bumi & 5,26 & 2,26 & 1,60 & 3,04 \\
\hline 19. & PT. Gudang Garam Tbk & 10,16 & 10,60 & 11,62 & 10,79 \\
\hline 20. & PT. HM Sampoerna Tbk & 27,27 & 30,03 & 29,38 & 28,89 \\
\hline 21. & PT. Bentoel Internasional Investama Tbk & $-12,94$ & $-15,49$ & $-3,41$ & $-10,61$ \\
\hline 22. & PT. Wismilak Inti Makmur Tbk & 9,77 & 7,86 & 3,32 & 6,98 \\
\hline 23. & PT. Indofarma Tbk & 0,43 & $-1,26$ & $-3,03$ & $-1,28$ \\
\hline 24. & PT. Kimia Farma Tbk & 7,73 & 5,89 & 5,44 & 6,35 \\
\hline 25. & PT. Merck Tbk & 22,22 & 20,68 & 17,08 & 19,99 \\
\hline 26. & PT. Kino Indonesia Tbk & 8,19 & 5,52 & 3,39 & 5,7 \\
\hline 27. & PT. Martina Berto Tbk & $-2,17$ & 1,24 & $-3,16$ & $-1,36$ \\
\hline 28. & PT. Mustika Ratu Tbk & 0,2 & $-1,1$ & $-0,3$ & $-0,4$ \\
\hline 29. & PT. Mandom Indonesia Tbk & 26,2 & 7,4 & 7,6 & 13,73 \\
\hline 30. & PT. Hartadinata Abadi Tbk & 15,43 & 16,59 & 13,51 & 15,17 \\
\hline
\end{tabular}

Sumber: Bursa Efek Indonesia (Data Diolah) 
Dari tabel 2 untuk data Return on Asset dinyatakan dalam satuan persen (\%). Dan untuk menghitung rata-rata Nilai Return on Total Asset dari tahun 2015,2016,dan 2017 menggunakan average pada MS.Excel.Untuk nilai AVG (average) diatas adalah untuk menghitung nilai rata-rata Return on Asset perusahaan dari tahun 2015, 2016, 2017.

\section{b) Hasil Pengolahan Data}

\section{Variabel Independent Modal Kerja}

Dari tabel 1 dapat dilihat bahwa perusahaan yang mempunyai rata-rata Modal Kerja terbesar berturut-turut adalah PT. Mandom Indonesia Tbk 95, PT.Delta Djakarta Tbk 91, PT. Akasha Wira International Tbk 83.488,PT. Nippon Indosari Corpindo Tbk 77, kemudian PT.Kino Indonesia Tbk 72.Terlihat bahwa 5 perusahaan yang mempunyai rata-rata Modal Kerja terbesar mampu mempergunakan aktivanya secara efisien.

\section{Variabel Dependen Retutn on Asset}

Dari tabel 3.2 dapat dilihat perusahaan yang mempunyai rata-rata ROA terbesar berturut-turut adalah PT. Multi Bintang Indonesia Tbk 39.82\%, PT.HM Sampoerna Tbk 28,89 \% , PT. Delta Djakarta Tbk 20.19\%, PT.Merck Tbk 19,99\% kemudian PT.Hartadinata Abadi Tbk 15,17\%. Terlihat bahwa 5 perusahaan yang mempunyai rata-rata return on asset terbesar mampu mempergunakan aktivanya secara efisien sehingga mampu menghasilkan laba.

\section{b. Pembahasan}

Dari hasil analisis data perusahaan diatas di peroleh data modal kerja (X) dan profitabilitas (Y) sehingga dapat disajikan sebagai berikut:

\section{a). Persamaan Regresi}

1) Tabel perhitungan untuk mencari konstanta $a$ dan $b$

Tabel 3.Perhitungan Konstanta a dan b

\begin{tabular}{|c|c|c|c|c|}
\hline Perusahaan & $\begin{array}{c}\text { Variabel } \\
\text { Bebas (X) }\end{array}$ & $\begin{array}{c}\text { Variabel tak } \\
\text { Bebas (Y) }\end{array}$ & $\mathbf{X Y}$ & $\mathbf{X}^{\mathbf{2}}$ \\
\hline 1 & 83 & 5,62 & 466,46 & 6.889 \\
\hline 2 & 1 & 0,73 & 0,73 & 1 \\
\hline
\end{tabular}




\begin{tabular}{|c|c|c|c|c|}
\hline 3 & 45 & $-3,33$ & $-149,85$ & 2.025 \\
\hline 4 & 52 & 10,79 & 561,08 & 2.704 \\
\hline 5 & 91 & 20,19 & $1.837,29$ & 8.281 \\
\hline 6 & 8 & 11,58 & 92,64 & 64 \\
\hline 7 & 12 & 5,42 & 65,04 & 144 \\
\hline 8 & -3 & 39,82 & $-119,46$ & 9 \\
\hline 9 & 5 & 10,89 & 54,45 & 25 \\
\hline 10 & 32 & $-2,60$ & $-83,2$ & 1.024 \\
\hline 11 & 77 & 7,51 & 578,27 & 5.929 \\
\hline 12 & 46 & 4,18 & 192,28 & 2.116 \\
\hline 13 & 35 & 8,78 & 307,3 & 1.225 \\
\hline 14 & 2 & 15,07 & 30,14 & 4 \\
\hline 15 & 59 & 5,36 & 316,24 & 3.481 \\
\hline 16 & -21 & 5,82 & $-122,22$ & 441 \\
\hline 17 & 13 & 12,06 & 156,78 & 169 \\
\hline 18 & 13 & 3,04 & 39,52 & 169 \\
\hline 19 & 19 & 10,79 & 205,01 & 361 \\
\hline 20 & 26 & 28,89 & 751,14 & 676 \\
\hline 21 & 4 & $-10,61$ & $-42,44$ & 16 \\
\hline 22 & 68 & 6,98 & 474,64 & 4.624 \\
\hline 23 & 13 & $-1,28$ & $-16,64$ & 169 \\
\hline 24 & 11 & 6,35 & 69,85 & 121 \\
\hline 25 & 37 & 19,99 & 739,63 & 1.369 \\
\hline 26 & 72 & 5,7 & 410,4 & 5.184 \\
\hline 27 & 30 & $-1,36$ & $-40,8$ & 900 \\
\hline 28 & 27 & $-0,4$ & $-10,8$ & 729 \\
\hline 29 & 95 & 13,73 & $1.304,35$ & 9.025 \\
\hline 30 & 58 & 15,17 & 879,86 & 3.364 \\
\hline Jumlah & 1.010 & 254,88 & $8.947,69$ & 61.238 \\
\hline
\end{tabular}

Data Diolah Tahun 2018

2) Menghitung nilai konstanta $a$ dan $b$

a. Menghitung nilai konstanta $\mathrm{b}$

$$
b=\frac{n \cdot \Sigma X Y-\Sigma X \cdot \Sigma Y}{n \cdot \Sigma X^{2}-(\Sigma X)^{2}}
$$




$$
\begin{aligned}
& b=\frac{30(8.947,69)-(1.010)(254,88)}{30(61.238)-(1.010)^{2}} \\
& b=\frac{11.001,9}{817.040}=0,01
\end{aligned}
$$

b. Menghitung nilai konstanta a

$$
\begin{aligned}
& a=\frac{\Sigma Y-b \cdot \Sigma X}{n} \\
& a=\frac{254,88-0,01(1.010)}{30} \\
& a=\frac{244,78}{30} \\
& a=8,15
\end{aligned}
$$

3) Membuat persamaan regresi linier sederhana

Berdasarkan hasil analisis regresi linear sederhana diperoleh, persamaan Pengaruh Modal Kerja terhadap Profitabilitas adalah sebagai berikut:

$$
\begin{aligned}
Y & =a+b . X \\
& =8,15-0,01 X
\end{aligned}
$$

Dimana : $\mathrm{Y}=$ profitabilitas

$$
\begin{aligned}
& \mathrm{a}=\text { konstanta } \\
& \mathrm{b}=\text { koefisien regrresi } \\
& \mathrm{X}=\text { modal kerja }
\end{aligned}
$$

\section{b). Nilai Korelasi Antara Variabel X dan Y}

1) Tabel perhitungan untuk mencari nilai korelasi

Tabel 4. Perhitungan Nilai Korelasi

\begin{tabular}{|c|c|c|c|c|c|}
\hline No. & $\begin{array}{c}\text { Modal Kerja } \\
(\mathbf{X})\end{array}$ & $\begin{array}{c}\text { Profitabilitas } \\
(\mathbf{Y})\end{array}$ & $\mathbf{X Y}$ & $\mathbf{X}^{\mathbf{2}}$ & $\mathbf{Y}^{\mathbf{2}}$ \\
\hline 1 & 83 & 5,62 & 466,46 & 6.889 & 31,5844 \\
\hline 2 & 1 & 0,73 & 0,73 & 1 & 0,5329 \\
\hline 3 & 45 & $-3,33$ & $-149,85$ & 2.025 & 11,0889 \\
\hline 4 & 52 & 10,79 & 561,08 & 2.704 & 116,4241 \\
\hline 5 & 91 & 20,19 & $1.837,29$ & 8.281 & 407,6361 \\
\hline 6 & 8 & 11,58 & 92,64 & 64 & 134,0964 \\
\hline 7 & 12 & 5,42 & 65,04 & 144 & 29,3764 \\
\hline 8 & -3 & 39,82 & $-119,46$ & 9 & $1.585,6324$ \\
\hline 9 & 5 & 10,89 & 54,45 & 25 & 118,5921 \\
\hline 10 & 32 & $-2,60$ & $-83,2$ & 1.024 & 6,76 \\
\hline
\end{tabular}




\begin{tabular}{|c|c|c|c|c|c|}
\hline 11 & 77 & 7,51 & 578,27 & 5.929 & 56,4001 \\
\hline 12 & 46 & 4,18 & 192,28 & 2.116 & 17,4724 \\
\hline 13 & 35 & 8,78 & 307,3 & 1.225 & 77,0884 \\
\hline 14 & 2 & 15,07 & 30,14 & 4 & 227,1049 \\
\hline 15 & 59 & 5,36 & 316,24 & 3.481 & 28,7296 \\
\hline 16 & -21 & 5,82 & $-122,22$ & 441 & 33,8724 \\
\hline 17 & 13 & 12,06 & 156,78 & 169 & 145,4436 \\
\hline 18 & 13 & 3,04 & 39,52 & 169 & 9,2416 \\
\hline 19 & 19 & 10,79 & 205,01 & 361 & 116,4241 \\
\hline 20 & 26 & 28,89 & 751,14 & 676 & 834,6321 \\
\hline 21 & 4 & $-10,61$ & 42,44 & 16 & 112,5721 \\
\hline 22 & 68 & 6,98 & 474,64 & 4.624 & 48,7204 \\
\hline 23 & 13 & $-1,28$ & $-16,64$ & 169 & 1,6384 \\
\hline 24 & 11 & 6,35 & 69,85 & 121 & 40,3225 \\
\hline 25 & 37 & 19,99 & 739,63 & 1.369 & 399,6001 \\
\hline 26 & 72 & 5,7 & 410,4 & 5.184 & 32,49 \\
\hline 27 & 30 & $-1,36$ & 40,8 & 900 & 1,8496 \\
\hline 28 & 27 & $-0,4$ & $-10,8$ & 729 & 0,16 \\
\hline 29 & 95 & 13,73 & $1.304,35$ & 9.025 & 188,5129 \\
\hline 30 & 58 & 15,17 & 879,86 & 3.364 & 230,1289 \\
\hline Jumlah & 1.010 & 254,88 & $8.947,69$ & 61.238 & $5.044,1278$ \\
\hline
\end{tabular}

Data Diolah Tahun 2018

2) Menghitung nilai korelasi $\left(\mathrm{r}^{2}\right)$

$$
\begin{aligned}
r^{2} & =\frac{n\left(\sum X Y\right)-\left(\sum X\right)\left(\sum Y\right)}{\sqrt{\left[n\left(\sum X^{2}\right)-\left(\sum X\right)^{2}\right]\left[n\left(\sum Y^{2}\right)-\left(\sum Y\right)^{2}\right]}} \\
r^{2} & =\frac{30(8.947,69)-(1.010)(254,88)}{\sqrt{\left[30(61.238)-(1.010)^{2}\right]\left[30(5.044,1278)-(254,88)^{2}\right.}} \\
& =\frac{11.001,9}{\sqrt{(817.040)(86.360,0196)}} \\
& =\frac{11.001,9}{\sqrt{70.559 .590 .414}} \\
& =\frac{11.001,9}{265.630,55249}=0,04
\end{aligned}
$$

Karena nilai korelasi bernilai nol artinya tidak ada korelasi sama sekali. Besaran Koefisien Korelasi berentang antara -1 sampai dengan 1, apabila koefisien sebesar -1 atau mendekati, hal ini menunjukan bahwa adanya hubungan linear negatif yang kuat sebaliknya apabila koefisien korelasi bernilai 1 atau mendekati hal ini menunjukan bahwa adanya 
hubungan linear positif yang kuat. Sedangkan apabila koefisien korelasi nol, hal ini menunjukan tidak ada hubungan linear antara pasangan variabel dalam penelitian.

1. Positif artinya jika variabel bebas (X) naik, maka variabel terikat (Y) naik.

2. Negatif artinya jika variabel bebas $(\mathrm{X})$ turun, maka variabel terikat (Y) turun.

\section{c). Koefisien Determinasi}

$$
\begin{aligned}
\mathrm{KP} & =(\mathrm{r})^{2} \mathrm{v} \times 100 \% \\
& =(0,04) 2 \times 100 \%=40 \%
\end{aligned}
$$

Angka tersebut mengandung arti bahwa Modal Kerja Berpengaruh terhadap Profitabilitas Sebesar 40\%. Sedangkan sisanya $(100 \%-40 \%=60 \%)$ dipengaruhi oleh variabel lain diluar model regresi ini.

\section{d). Menghitung nilai $t_{\text {Hitung }}$}

Rumus:

$$
\begin{aligned}
t \text { hitung } & =\frac{r \sqrt{n-2}}{\sqrt{1-(r)^{2}}}=\frac{0,04 \sqrt{30-2}}{\sqrt{1-(0,04)^{2}}} \\
& =\frac{0,211}{0,998}=0,211
\end{aligned}
$$

\section{e). Menentukan Nilai $\mathbf{t}_{\text {tabel }}$}

nilai $t_{\text {tabel }}$ dapat dicari dengan menggunakan tabel $t$-student

rumus $=$

$$
\begin{aligned}
& \mathrm{t}_{\text {tabel }}=\mathrm{t}_{(\mathrm{a} / 2)(\mathrm{n}-2)} \\
& =\mathrm{t}_{(0,05 / 2)(30-2)}=\mathrm{t}_{(0,025)(28)}=2,048
\end{aligned}
$$

\section{f). Membandingkan nilai $\mathbf{t}_{\text {tabel }}$ dan $\mathbf{t}_{\text {hitung }}$}

Tujuan membandingkan nilai $\mathrm{t}_{\text {tabel }}$ dan $\mathrm{t}_{\text {hitung }}$ adalah untuk mengetahui apakah hipotesis ditolak atau diterima berdasarkan kaidah pengujian.

Ternyata $\mathrm{T}_{\text {hitung }}=0,211>\mathrm{t}$ tabel 2,048 maka Sehingga dapat disimpulkan bahwa Hipotesis diterima, yang berarti bahwa "Ada pengaruh Modal Kerja (X) terhadap Profitabilitas (Y). 


\section{KESIMPULAN}

Bedasarkan hasil penelitian dan pembahasan mengenai analisis pengaruh modal kerja terhadap profitabilitas pada perusahaan manufaktur yang terdaftar Di Bursa Efek Indonesia (BEI) dapat disimpulkan hasil analisis regresi sederhana menunjukan bahwa modal kerja berpengaruh terhadap profitabilitas pada perusahaan manufaktur yang terdapat dibursa efek indonesia pada sektor industry barang konsumsi. Hal ini dapat dilihat dari nilai $\mathrm{t}_{\text {hitung }}$ lebih besar dari nilai $\mathrm{t}_{\text {tabel }}: 0,211>2,048$.

\section{SARAN}

Dari berbagai permasalahan yang ada, maka dalam rangka perbaikan kedepan beberapa saran dapat dikemukakan antara lain, penelitian mengenai modal kerja terhadap profitabilitas perusahaan diberbagai sektor industri masih relatif terbatas, sedangkan dampaknya bagi perusahaan sangatlah besar.Untuk itu bagi peneliti selanjutnya, diharapkan untuk menambahkan variable-variabel lain dalam penelitian analisis pengaruh modal kerja terhadap profitabilitas pada perusahaan manufaktur yang terdaftar di bursa efek Indonesia.

\section{DAFTAR PUSTAKA}

[1] Agus, Sartono. 2008. Manajemen Keuangan Teori dan Aplikasi Edisi Empat. Yogyakarta: BPFE

[2] Kasmir. 2010. Pengantar Manajemen Keuangan.Jakarta: Kencana Prenada Media Group.

[3] Eva Larasati dan Selmita Peranan.Pengaruh Modal Kerja Terhadap Profitabilitas Studi pada Perusahaan Manufaktur yang Terdapat di Bursa Efek Indonesia. Jurnal El-Muhasaba, Volume 4 Nomor 1.

[4] Aulia, Rahma. 2011. Pengaruh Modal Kerja dan Profitabilitas Perusahaan(Studi pada Perusahaan Manufaktur PMA dan PMDN yang Terdaftar di BEI Periode 2004 - 2008).Skripsi FE Universitas Diponegoro.

[5] Julkarnain. 2012. Pengaruh Modal Kerja, Perputaran Modal Kerja, Perputaran Kas, dan Perputaran Piutang Terhadap Profitabilitas Pada Perusahaan Barang Konsumsi Yang Terdafatar di Bursa Efek Indonesia Tahun 2008-2011. Skripsi S1 Universitas Maritim Raja Ali Haji, Tanjung Pinang, Diakses pada 10 Mei 2019 dari jurnal.umrah.ac.id.

[6] Kasmir. 2008. Analisis Laporan Keuangan. Jakarta: PT Raja Grafindo Persada. 
[7] Arinda Putri Nawalani. 2015. Pengaruh Modal Kerja Terhadap Profitabilitas pada perusahaan FOOD AND BEVERAGES Di Bursa Efek Indonesia.Journal of Business and Banking, Volume 5 Nomor 1.

[8] Sugiyono, 2014. Metode Penelitian Bisnis, Edisi Revisi, Cetakan Kedelapan Belas, Bandung:Alfabeta.

[9] Sekaran, Uma., dan Roger Bougie 2013. Research Methods For Business Edisi 4. Buku 2, Jakarta: Wiley

[10] Brigham, Eugene F dan Houston, Joel F. 2006. Dasar-Dasar Manajemen Keuangan. Jakarta: Salemba Empat.

[11] Ghozali, Imam. 2013. Aplikasi Analisis Multivariate dengan Program SPSS. Edisi Ketujuh. Semarang : Badan Penerbit Universitas Diponegoro

[12] Soepemo,Bambang. 2009. Statistik Terapan Dalam Penelitian Ilmu-Ilmu Sosial Dan Pendidikan. Jakarta: PT. Rineka Cipta.

[13] Munawir, S. 2014. Analisis Laporan Keuangan. Yogyakarta: Liberty.

[14] Siregar,Syofian. 2013. Metode Penelitan Kuantitatif Di Lengkapi Dengan Perbandingan Perhitungan Manual dan SPSS. Jakarta: Kencana

[15] Indriantoro, Nur., dan Supomo, Bambang. (2013). Metodologi Penelitian Bisnis Untuk Akuntansi \& Manajemen. Yogyakarta: BPFE. 